\title{
Protein/ Creatinine Ratio in Random Urine Sample for Quantitation of Proteinuria Compared with 24 Hour Urine Collection in Patients with Pre-Eclampsia
}

\author{
Sharief $M^{*}$ and Khudier AW \\ Department of Gynecology and Obstetrics, University of \\ Basrah, Iraq \\ *Corresponding author: Maysoon Sharief, \\ Department of Gynecology and Obstetrics, College of \\ Medicine, University of Basrah, Basrah, Iraq
}

Received: December 06, 2018; Accepted: J anuary 30, 2019; Published: February 06, 2019

\begin{abstract}
Objective: To evaluate the diagnostic value of protein/creatinine $(p / c)$ ratio in a single voided urine sample for quantitation compared to those of $24 \mathrm{~h}$ urine sample in patient with pre-eclampsia.
\end{abstract}

Patients and Methods: A prospective study was conducted in Basrah maternity and child hospital during the period from October 2013 to October 2014. The study involved 60 pregnant women with hypertension attending the antenatal clinic and admitted to obstetrics ward regardless the severity of the disease. The main measurement was estimation the urinary protein to urinary creatinine ratio by random direct measurement and a 24-hour urinary protein excretion. The data obtained was statically analyzed.

Results: Out of 60 patients with gestational hypertension, 49 patients had significant proteinuria ( $>300 \mathrm{mg} /$ day) and 11 patients had proteinuria less than ( $300 \mathrm{mg} /$ day). Also, 17 out of 60 patients had $\mathrm{p} / \mathrm{c}$ ratio $<3 \mathrm{mg} / \mathrm{dl}$ and 43 patients had $\mathrm{p} / \mathrm{c}$ ratio $>3.5 \mathrm{mg} / \mathrm{dl}$. The $\mathrm{p} / \mathrm{c}$ ratio was able to correctly identify 42 out of 49 patients with significant proteinuria. It has been estimated that protein/creatinine ratio with sensitivity of $81.6 \%$, specifity of $27.7 \%$ positive predictive value $93 \%$, negative predictive value $70 \%$, false positive rate $27.2 \%$, false negative rate $18.3 \%$.

Conclusion: The study suggest that the $\mathrm{p} / \mathrm{c}$ ratio in single voiding urine is highly accurate test $(P<0.01)$ for discriminating between in significant proteinuria. This could be a reasonable alteration to the 24-hour collection for detection of significant proteinuria in hospitalized pregnant women with suspected preeclampsia.

Keywords: Pre-eclampsia; Protein/creatinine ratio; Proteinuria; Urinary system

\section{Introduction}

Precamplsia is idiopathic disorder of pregnancy characterized by hypertension and proteinuria [1]. About $10 \%$ of women will develop Pre-eclampsia in the first pregnancy. It usually occurs after 20 weeks of gestation most often near term [1]. In severe disease there may be thrombocytopenia, hemolysis, impair liver and renal function, swelling, dyspnea or visual disturbance [2].

Maternal death worldwide is $12 \%$ and is due to hypertension disorder of pregnancy and it has been shown that patients with significant proteinuria have significant reduction in mean birth weight for gestational age due to intra-uterine growth retarded compared to the patients with hypertension alone. While, the mean birth weight for gestational age among women with hypertension alone same as normotensive [3].

So, early detection and proper management of patients with proteinuria is therefore, beneficial for mother and fetus [3]. Preeclampsia can be perceived as an Pre-eclampsia impairment of maternal immune system which prevent it from recognizing the fetoplacental unit. Excessive production of immune cells causes secretion of tumor necrosis factors alpha and induce apoptosis of extra villous cytotrophlpast. The Human Leukocyte Antigen (HLA) system also appears to play a role in defective invasion of the spiral arteries [1].

The use of the term albuminuria to describe proteinuria is incorrect because there is an increase permeability to large molecular weight protein with any glomerulopathy. Thus, albumin excretion is accompanied by other protein such as globulines, haemoglobuline and transferring [4]. Normally, those of a large protein molecules are not filtered by the glomeruli and thus their appearance in urine signifies glomerulopathic process [5].

Proteinuria of Pre-eclampsia involves predominantly high molecular weight proteins such as albumin and large amount of IgM, IgG, fibronectin and B2 microglobulin are found in urine. It is caused by reversible structural alteration of glomerular filter resulting from injury of endothelial cells in glomerular capillaries [6]. Both proteinuria and alteration of glomerular histology develop late in the course of pre-eclampsia [7].

Therefore, the aim of the study is to evaluate the diagnostic value 
of protein/creatinine $(\mathrm{p} / \mathrm{c})$ ratio in a single voided urine sample for quantitation compared to those of $24 \mathrm{~h}$ urine sample in patient with pre-eclampsia.

\section{Patients and Methods}

This prospective study was conduct in AL-Basrah Maternity and Child Hospital during the period from October 2013 to October 2014. Sixty inpatient pregnant women more than 20 weeks with gestational hypertension (defined as blood pressure more than 140/90 $\mathrm{mmHg}$ in 2 different measurements obtained at interval more than 6 hours). Their ages ranged between 16-39 years and parity (0-6) .

Patients with chronic renal disease, chronic hypertension, diabetes mellitus, bacteruria, urinary tract infection or catheter not insert after rupture of membrane were excluded from the study.

On admission all patient were interviewed and examined carefully, gestational age was determined by the Last Menstrual Period (LMP) and any previous Ultra Sound (U/S). Then each patient was asked for:-

$24 \mathrm{~h}$ urine collection on clean bottle was started before midday. First morning sample was discarded and the time was noted .

A single voided urine specimen for spot protein/creatinine ratio was obtained as soon as possible after the $24 \mathrm{~h}$ collection.

Morning sample was excluded for estimation of urine $\mathrm{P} / \mathrm{C}$ ratio.

The data obtained was statistically analyzed.

Sensitivity $=\frac{\text { True positive }}{\text { True positive }+ \text { False negative }} \times 100$

Specificity $=\frac{\text { True negative }}{\text { False positive }+ \text { True negative }} \times 100$

Positivity predictive value $=\frac{\text { True positive }}{(\text { True positive }+ \text { False positive })}$

Negative predictive value $=\frac{\text { True negative }}{\text { True negative }+ \text { False positive }}$

\section{Results}

\section{Study population}

A total of 60 pregnant women were admitted for the evaluation and the age group 30-39 contributed the highest percentage (45\%) followed by age $\geq 20-29$ (34\%) Table 1 .

Table 2 shows the distribution of the patients according to the parity. Majority of the studied group were multiparty patient $\geq 3$ (39\%) followed by para 2 (25\%) and prim gravida (20\%).

Table 3 shows the distribution of the studied subjects according to 24 urine protein. Out of 60 patients $26(34 \%)$ had significant protein urea of the range more than $300 \mathrm{gm} /$ day.

Table 4 shows the distribution of patients according to $\mathrm{p} / \mathrm{c}$ ratio in spot urine sample. Among 60 patients, $17(28 \%)$ had p/c ratio less than $3.5 \mathrm{mg} / \mathrm{dL}$ and $26(44 \%)$ greater than $4.5 \mathrm{mg} / \mathrm{dL}$.
Table 1: Distribution of the studied subjects $(n=60)$ according to age.

\begin{tabular}{|c|c|c|}
\hline Age (in years) & Number (n) & Percentage (\%) \\
\hline$<20$ & 13 & 21 \\
\hline $20-29$ & 20 & 34 \\
\hline $30-39$ & 27 & 45 \\
\hline Total & 60 & 100 \\
\hline
\end{tabular}

Table 2: Distribution of the studied subjects ( $n=60)$ according to parity.

\begin{tabular}{|c|c|c|}
\hline Parity (p) & Number (n) & Percentage (\%) \\
\hline 0 & 12 & 20 \\
\hline 1 & 10 & 16 \\
\hline 2 & 15 & 25 \\
\hline$\geq 3$ & 23 & 39 \\
\hline Total & 60 & 100 \\
\hline
\end{tabular}

Table 3: Distribution of the studied subjects $(n=60)$ according to 24 hour urine protein.

\begin{tabular}{|c|c|c|}
\hline 24 hour urine protein (mg/day) & Number (n) & Percentage (\%) \\
\hline$<300$ & 11 & 18 \\
\hline $300-400$ & 23 & 39 \\
\hline$>400$ & 26 & 43 \\
\hline Total & 60 & 100 \\
\hline
\end{tabular}

Table 4: Distribution of the studied subjects $(n=60)$ according to protein creatinine ratio.

\begin{tabular}{|c|c|c|}
\hline Protein creatinine ratio $\mathbf{~ m g / d L}$ & Number (n) & Percentage (\%) \\
\hline$<3.5$ & 17 & 28 \\
\hline $3.5-4.5$ & 17 & 28 \\
\hline$>4.5$ & 26 & 44 \\
\hline Total & 60 & 100 \\
\hline
\end{tabular}

Table 5: Comparison of protein/creatinine ratio in single voided urine sample to 24 hour urine protein in the studied subjects $(n=60)$.

\begin{tabular}{|c|c|c|c|}
\hline \multirow{2}{*}{$\begin{array}{l}\text { Protein/ creatinine ratio in single voided urine } \\
\text { sample }\end{array}$} & \multicolumn{2}{|c|}{$\begin{array}{c}24 \text { hour urine } \\
\text { protein }\end{array}$} & \multirow{2}{*}{$\begin{array}{c}\text { Total } \\
(n)\end{array}$} \\
\hline & $\begin{array}{l}\text { Positive } \\
300 \mathrm{mg}\end{array}$ & $\begin{array}{l}\text { Negative } \\
<300 \mathrm{mg}\end{array}$ & \\
\hline Positive 3.5 mg/dL & $40 \mathrm{TP}$ & $3 \mathrm{FP}$ & 43 \\
\hline Negative $<3.5 \mathrm{mg} / \mathrm{dL}$ & $9 \mathrm{FN}$ & $8 \mathrm{TN}$ & 17 \\
\hline Total & 49 & 11 & 60 \\
\hline
\end{tabular}

Table 5 shows the comparison of $\mathrm{p} / \mathrm{c}$ ratio in single voided urine sample to $24 \mathrm{~h}$ urine protein in the studied group. Out of the total 60 patients with gestational hypertension 49 patients had $24 \mathrm{~h}$ urine protein excretion more than $300 \mathrm{mg}$ and out of 49 positive protein urea there was 40 positive $\mathrm{p} / \mathrm{c}$ ratio and 9 patient were false negative (protein/creatinine ratio $<0.3 \mathrm{mg} / \mathrm{dL}$ ) on the other hand 11 patients with gestational hypertension had negative $24 \mathrm{~h}$ protein urine $(<300$ $\mathrm{mg}$ ) out of them 3 patients were false positive for $\mathrm{p} / \mathrm{c}$ ratio $>3.5 \mathrm{mg} /$ $\mathrm{dL}$ and 8 patients with true negative $(<3.5 \mathrm{mg} / \mathrm{dL})$.

Table 6 shows test of validity for $\mathrm{p} / \mathrm{c}$ ratio in patients with preeclampsia. $\mathrm{P} / \mathrm{c}$ ratio had $81.6 \%$ sensitivity, $72.7 \%$ specificity and positive predictive value of $93 \%$, negative predictive value of $70 \%$, false negative rate $27.2 \%$, false negative rate $18.3 \%$, Odds ratio $11.85 \%, \mathrm{P}<0.01$. 
Table 6: Diagnostic value of protein/creatinine ratio patients with suspected preeclampsia $(n=60)$ compared to 24 hour urine protein.

\begin{tabular}{|l|c|}
\hline \multicolumn{1}{|c|}{ Test of validity } & Protein/ Creatinine ratio \\
\hline Sensitivity & $81.60 \%$ \\
\hline Specificity & $72.70 \%$ \\
\hline Positive Predictive value & $93 \%$ \\
\hline Negative Predictive value & $70 \%$ \\
\hline False Positive rate & $27.20 \%$ \\
\hline False Negative rate & $18.30 \%$ \\
\hline
\end{tabular}

\section{Discussion}

Pre-eclampsia with various severity (mild, moderate, severe), proteinuria is estimated $\geq+1$ on dipstick test or urine protein $\geq 300 \mathrm{mg} / 24 \mathrm{~h}$ is mandatory for diagnosis and evaluation of the severity of pre-eclampsia beside maternal and perinatal morbidity and mortality increased with amount of proteinuria [8]. Several methods are available for measuring proteinuria but $24 \mathrm{~h}$ urine protein excretion has long been regarded as the gold standard. This test has some disadvantages such as inconvenience for patients, inaccuracy due to incomplete collection, cost and delay of diagnosis and management, which make it difficult for wide use for clinician [9].

One of most commonly used is the urinary dipstick test because it is simple and cheap but this method has high false positive and false negative rate beside associated with fluctuation throughout the day due to water intake, exercises, diet, posture, and properly trained laboratory staff $[9,10]$. Thus, the determination of the protein/ creatinine ratio in single urine sample in pregnancy seems a sufficient valid method to assess the amount of protein excretion.

The socio demographic variable shows that the peak age more than 30 years ( $45 \%$ ) and multiparty ( $\geq 3$ ) $39 \%$ which in contrast to what is usually reported and shows that prim gravida and age peak of 20-29 years to be at high risk of developing pre-eclampsia [11] Various studies have shown that women aged more than 40 years twice risk of pre-eclampsia regardless of parity [12].

In this study, sensitivity of $81.6 \%$ allows the clinician to correctly identify greater than 8 out of 10 cases a significant protein urea Specificity of a diagnostic test is the probability that patient without proteinuria will have a negative result. In the present study, the specificity was $(72.7 \%)$ which higher than urine dipstick test had a (47\%) specificity. The false positive rate of $(27 \%)$ in contrast with studies have demonstrated that false positive reaction was (14\%) false positive lead to error in diagnosis and early interference increase maternal and fetal complications. Positive predictive value (93\%) and negative predictive value $(70 \%)$ which is higher than that for the dipstick test $(48 \%)$ which demonstrated the unreliability of the dipstick test.
The effectiveness or validity of a test is important to aid clinical decision making the above method is faster in comprising to $24 \mathrm{~h}$ protein collections as well as the difficult in ensuring complete collection make it unfit for routine use in clinical practice.

\section{Conclusion}

$\mathrm{P} / \mathrm{c}$ ratio had a sensitivity of $81.6 \%$, which will allow the clinician to correctly identify greater than 8 out of 10 cases of significant proteinuria. Therefore, routine use of either $\mathrm{p} / \mathrm{c}$ ratio quantitation of proteinuria in patient with pre-eclampsia could be adapted which is reliable, relatively faster and correlating well with $24 \mathrm{~h}$ urinary protein excretion in clinical practice.

\section{References}

1. Davey DA. Hypertensive disorder of pregnancy, Dewhurt $s$ textbook of obstetrics \& gynecology for postgraduate, J Dewhurst, 8 edition, whitfieldch R. University of Glascow. 2011; 102-103.

2. Sibai BM, Gordont, Thom E, Caritis SN, Klebanoff M, McNellis D, et al. Risk factors for pre-eclampsia in healthy nulliparous women: a prospective multicenter study. The National Institute of Child Health and Human Development Network of Maternal-Fetal Medicine Units. Am J Obstet Gynecol. 1995; 172: 642-648.

3. Studd J. High Risk Pregnancy. Progress in Obstetrics \& Gynecology. 1989 7: 56-74

4. Yamamoto $T$, Yoshimura $S$, Sasamori $Y$, Sakamoto $T$, Ogino $M$, Kambegawa A, et al. Analysis of urinary protein by immunoblot method using unconcentrated urine in pre-eclampsia. Asia-Oceania J Obstet Gynecol. 1992; 182: 177-185.

5. Cunningham FG, Leveno KJ, Bloom SL, Dashe SJ, Hoffman LB, Casey MB et al. Williams Obstetrics, 23 ${ }^{\text {rd }}$ edn. New York, McGraw-Hill. 2010; 711.

6. Schiff E, Freidman SA, Kao L, Sibai BM. The importance of urinary protein excretion during conservative management of severe pre-eclampsia. Am J Obstet Gynecol. 1996; 175: 1313-1315.

7. Arias F, Mancilla-Jimenez R. Hepatic fibrinogen deposits in pre-eclampsia. New Engl J Med. 1986; 295: 578-582.

8. Haas DM, Sabif MC, Mamara M, Rivera-Alsina M. Comparing ambulatory spot urine / creatinine ratio and 24-hour urine protein measurement in normal pregnancies. J Maternal Fetal Neonatal Med. 2003; 14: 233-236.

9. Saudan PJ, brown MA, Farrell T, Shaw L. Improved methods of assessing protein urea in hypertensive pregnancy. Br J Obstet Gynaecol. 1997; 109: 1159-1164

10. Rodriguez-Thompson $\mathrm{P}$, Lieberman ES. Use of random urinary protein creatinine ratio for the diagnosis of significant protein urea during pregnancy. Am Obstet Gynecol. 2001; 185: 808-811.

11. Rizk DE, Agarwal MM, Pathan JY, Obineche EN. Predicting protein urea in hypertensive pregnancies with urinary protein/creatinine or calcium/creatinine ratio J Perinatal. 2007: 27: 272-276.

12. Onah HE. Asurvey of arterial blood purser in pregnant women 1996, FM Co G Dissertatron National Postgraduate Medical College of Nigeria. 104.

\footnotetext{
Austin J Reprod Med Infertil - Volume 6 Issue 1 - 2019 ISSN : 2471-0393 | www.austinpublishing group.com Sharief et al. (C) All rights are reserved
}

Citation: Sharief M and Khudier AW. Protein/Creatinine Ratio in Random Urine Sample for Quantitation of Proteinuria Compared with 24 Hour Urine Collection in Patients with Pre-Eclampsia. Austin J Reprod Med Infertil. 2019; 6(1): 1051. 